\title{
Avrupa Birliği ve Geleceği
}

Araştırma Makalesi /Research Article

\section{Mehmet SOYTÜRK ${ }^{1}$}

ÖZ: Avrupa Kömür Çelik Topluluğu (AKÇT) Antlaşması ile üye devletler daha önce örneği görülmemiş bir şekilde egemenliklerinin bir kısmını kendi aralarında oluşturmuş oldukları bir üst kuruma devretmişlerdir. Başarıl ekonomik gelişmelerin ardından Avrupa'daki bu örnek iş birliği, bütün ekonomi alanların kapsayacak şekilde Avrupa Ekonomik Topluluğu Antlaşması (AET) ile ekonominin bütün sektörlerine yayılmıştır. AKÇT Antlaşmasın imzalanmış olduğu yıldan bu yana birçok değişikliğe uğramıştır. Önce Avrupa Ekonomik Topluluğu (AET), sonra Avrupa Topluluğu (AT) ve nihayetinde Avrupa Birliği (AB) adını alarak, üye devletler arasindaki iş birliğini ekonomik alandan siyasi alana geçmesini sağlamıştır. AB, 2016 yllında Büyük Britanya'da yapılan halk oylamasının sonucu ile büyük bir şok yaşamıştır. Büyük Britanyalıların çoğunluğunun AB'den ayrılma yönünde oy kullanmış olması, "acaba AB dağllma sürecine mi girdi?" sorusunun oluşmasına sebep olmuştur. Brexit ile başlayan bu sürecin devamında AB'yi çok önemli gelişmelerin beklediği kesindir. Bu süreçte Birliğin geleceği, alınacak önlemler ve belirlenecek siyasete göre şekillenecektir.

Anahtar Sözcükler: Avrupa Birliği, Brexit, Avrupa Birliği’nin Geleceği

Jel Kodu: F51, J17, N14, F15

\section{European Union and its Future}

ABSTRACT: With the ECSC, the member states transferred their sovereignty to a higher institution, which they formed among themselves, in an unprecedented manner. Following the successful economic developments, this exemplary cooperation in Europe has spread to all sectors of the economy with the Convention of European Economic Community (EEC) covering all economic areas. It has undergone many changes since the year the European Coal and Steel Community Agreement was signed. It was first named the European Economic Community (EEC), then the European Community, and finally the European Union (EU), and enabled the cooperation between the member states to shift from the economic sphere to the political sphere. The fact that the majority of Great Britons voted to leave the European Union in 2016 cast doubt on the integrity of the European Union. It is certain that very important developments await the European Union in the continuation of this process that started with Brexit.

Keywords: European Union, Brexit, The Future of the EU

JEL Codes: F51, J17, N14, F15

Geliş Tarihi / Received: 07/09/2020

Kabul Tarihi / Accepted: 06/10/2020

\section{Giriş}

${ }^{1}$ Dr. Öğr. Üyesi, Karadeniz Teknik Üniversitesi, mehmetsoyturk@ktu.edu.tr, orcid.org/00000002-9011-3660. 
Nobel Komitesi, 2012 yılında Barış Ödülü’nün Avrupa Birliği’ne (AB) verilmesinin gerekçesini, AB'nin Avrupa'yı savaş kıtasından bir barış kıtasına dönüştürmesi olarak açıklamıştır. Açıklamasının devamında da AB'nin en büyük kazanımının barış, uzlaşma, demokrasi ve insan hakları için verilen mücadele olduğunu ifade etmiştir (Brasche, 2013; 499).

Avrupa Kıtası için vermiş olduğu mücadeleden dolayı daha sekiz yıl kadar önce Nobel Barış Ödülü'ne layık görülen $\mathrm{AB}$, günümüzde dağılma tehlikesi ile karşı karşıyadır. Son yıllardaki Brexit, ırkçı aşırı sağ partilerin giderek rağbet görmeleri ve Mülteciler Sorunu gibi önemli gelişmeler AB'yi bekleyen son derece önemli sorunlardır. Birliğin geleceğini, Birlik kurumlarının bu sorunlarla nasıl mücadele edeceği şekillendirecektir. AB'yi bekleyen ve Birliğin geleceği için belirleyici olan diğer sorunlar ise üye ülkelerdeki yüksek genç işsizlik oranları, bütçe açıkları ve Finans sektöründeki krizlerdir. Daha önce benzer krizlere maruz kalmamış olan $\mathrm{AB}$, bu krizlere karşı nasıl bir mücadele vereceği ile kendi geleceğini de belirleyecektir.

AB'nin, şimdiye kadar uygulamış olduğu kriz çözüm stratejilerini uygulamaya devam ettiği takdirde, sorunlarına daimî çözümler üretemeyeceğini ifade etmekte bir sakınca bulunmamaktır. Birleşik Krallığın Brexit ile AB'den ayrılmış olması ve Birliğe üye ülkelerde aşırı sağ popülist partilerin sürekli artan oy oranlarının engellenememesi, bize AB'nin geçmişte uygulamış olduğu politikalar ile çözüme ulaşmasının mümkün olmadığını göstermektedir. AB'nin karşı karşıya kalmış olduğu sorunları, alışılagelen yöntemlerle çözmeye çalışması, sorunları çözmeyip sadece geçiştireceği anlamına gelmektedir.

$\mathrm{AB}$, son y1llarda kurumlar arasındaki ve genel anlamda Birlik içerisindeki uyumu derinleştirmeye çalışırken, diğer taraftan mülteciler krizi, küresel ekonomik kriz ve aşırı sağın yükselmesi gibi sorunlara da nasıl bir duruş sergileyeceğinin mücadelesini vermek durumunda kalmıştır. Birliğin kısa tarihinde maruz kalmış olduğu bu gelişmelerle üyelerin farklı farklı tutumlarının Birlik kurumlarına tecrübe kazandırdığı kesindir. Birlik Kurumları geçmişteki sorunlarla mücadele ederken kazanmış olduğu tecrübeleri, aslında uzun zamandır var olan ve günümüzde iyice su üstüne çıkmış olan sorun ve krizlere karşı uygulayacağı politikalarla Birliğin geleceğini şekillendirecektir. Şayet tecrübelerinden gerekli dersi çıkarmayan bir $\mathrm{AB}$, şimdiye kadar uygulamış olduğu paradigma ile sorunları çözmeye çalışacak olursa Birliğin geleceğini karanlık günler beklemesi muhtemeldir.

$\mathrm{Bu}$ çalışmanın amacı AB'nin geleceğini belirleme potansiyeline sahip olan sorunları tespit edip analizini gerçekleştirmektir. $\mathrm{Bu}$ sorunların tespitinde ve analizinin gerçekleştirilmesinde faydalanılan birincil kaynaklar çeşitli $A B$ kurumlarının internet sayfalarında yayınlamış oldukları basın bildirileri, $\mathrm{AB}$ Kurum başkanlarının beyanları ve ikincil kaynak olarak konu ile ilgili yazılmış olan Kitap ve makalelerdir. 
Makale üç bölümden oluşmaktadır. Birinci bölümde Avrupa'da, Birliğin kurulmasının sebepleri ve Birliğe giden yolda yapılan Antlaşmalar sebepleri ile beraber açıklanmaya çalışılmıştır. İkinci bölümde AB'nin geleceğini belirleme potansiyeline sahip olan sorunlar sıralanmış ve Birliğin geleceğini belirleme potansiyeline sahip olma nedenleri analiz edilmeye çalışılmıştır. Sonuç ve tartışmadan oluşan son bölümde ise AB'nin dağılma sürecine girmemesi ve gelecekte de var olabilmesi için yapması gerekenler tartışılmaya çalışılmıştır.

\section{Avrupa'da Birliğe Giden Yol}

Avrupa Kömür Çelik Topluluğu'nun (AKÇT) 1952 yılında kurulması Avrupa Birliği'ne (AB) giden yolun başlangıcı olarak kabul edilmektedir. AKÇT'nin kuruluş amaçlarından biri, üyeler arasında barışın tesis edilip güvence altına alınmasıydı. Daha farklı bir şekilde ifade edecek olursak, Fransa'nın Almanya'nın tekrar güçlenip hem kendisi hem de Avrupa için tehlike oluşturma ihtimalini ortadan kaldırma amacının sonucu olarak AKÇT kurulmuştur. Kıta Avrupa'sının en önemli ülkeleri olan Fransa ve Almanya arasında Fransa Kralı Napolyon döneminden itibaren AKÇT'nin kuruluşuna kadar olan süreçte üç büyük savaş meydana gelmiş ve sonuç Kıta Avrupası açısından felâket olmuştur. Bu savaşların ilki 1870-71 yıllarında Prusya Krallığı ile II. Fransa İmparatorluğu arasındaki, diğer iki tanesi ise 20.yüzyılın kanlı I. ve II. Dünya Savaşları'dır. Prusya Kralı II. Wilhelm'in, II. Fransa İmparatorluğu'na karşı yürüttüğü savaşta Baden Würtenberg ve Bavyera prenslikleri tarafından desteklenmiştir. Prusya'nın uzun yıllardır amacı olan Almanya'nın birleşmesi yönünde böylece önemli bir adım atılmıştır. Prusya ve Fransa arasında meydana gelen bu savaşın sonucunda Alman prensliklerinin Almanya bünyesinde birleşirken mağlup olan Fransa'da ise III. Napolyon'un tahttan düşmesine sebep olmuştur (Schmidt, 2016; 16-17). Yirminci yüzyılda meydana gelen Birinci ve İkinci Dünya savaşlarında Almanya tarafından saldırıya uğrayan ve mağdur edilen Fransa, bu savaşlara artık bir son verilmesi gerektiğini düşünerek savaşları ortaya çıkarabilecek olası sebepleri ortadan kaldırma amacıyla hareket etmiştir. Fransa hem I. Dünya Savaşı'ndan hem de II. Dünya Savaşı'ndan sonra Almanya'nın bir bütün olarak değilse bile, sanayisinin bel kemiği olan Ruhr Bölgesi'nin kontrol altına alınması için çabalamıştır. Avrupa devletleri arasında Demir Çelik ve Madencilik sektörlerinde iş birliğine gidilip ortak hareket edilmesini sağlamakta bu çabaların bir sonucudur. Demir çelik ve madencilik sektörünün merkezi olan Ruhr Bölgesindeki sanayiin kontrol altına alınarak, Almanya'nın tehlike oluşturma ihtimalinin önüne geçilmek istenmiştir. Almanya ile beraber Avrupa'nın önde gelen ülkeleri arasında Demir Çelik ve Madencilik sektöründe oluşturulan iş birliği ile devletler karşılıklı olarak birbirlerini kontrol edebilecek duruma gelmişlerdir.

Avrupa'da Kömür ve Çelik alanlarında AKÇT ile başlatılan iş birliği ile önemli sonuçlara ulaşılmasının sonucunda kurucu altı ülke arasındaki iş birliğinin bütün ekonomik alanlara yayılması kararı alınmıştır. Bu kararı resmiyete dökmek amacıyla 1957 yılında Roma'da Roma Antlaşması ile Avrupa Ekonomik 
Topluluğu (AET) kurulmuştur. AKÇT Antlaşmasını imzalayan Almanya, Fransa, İtalya, Belçika, Hollanda ve Lüksemburg, yeni Roma Antlaşması ile Avrupa Ekonomik Topluluğunu (AET) oluşturmuşlardır. AKÇT'nin olası savaşları önlemenin yanı sıra bir diğer amacı da ortak bir ekonomik pazar oluşturarak üye devletlerin ekonomik kalkınmalarını sağlayıp refah seviyelerini yükseltmekti (Sonnickson, 2014; 57). Antlaşmadaki temel hedeflere ulaşmayı başaran üye devletler, iş birliklerini yeni oluşturulan AET ile kömür ve çelik sektöründen ekonominin bütün alanlarına yaymışlardır. Avrupa'daki birleşmenin ikinci aşaması olan AET'nin kurulması ile tanımlanan hedeflerin başında malların, hizmetlerin, sermayenin ve işgücünün serbest hareket edebildiği bir ortak pazarın oluşturulması gelmekteydi (von Eynern, 1973; 100).

AET ile paralel olarak kurulan Avrupa Atom Enerjisi Topluluğu (AAET) ile de üye devletlerarasında Nükleer enerji alanında iş birliğinin artırılması düşünülmekteydi. AET üyeleri arasında kurulan AAET'nin (Euratom) amacı üye devletlerin Nükleer enerji alanında iş birliğini artırmak ve aynı zaman da Nükleer enerjinin barışçıl amaçlarda ve güvenli bir şekilde kullanılmasını sağlamaktı (Schrafstetter, 199; 33). Kısa zaman içerisinde kurulan bu toplulukların 1967 yılındaki Füzyon Antlaşmasına kadar hepsi ayrı birer konsey ve komisyonlara sahiplerdi. Bu karmaşayı ortadan kaldırmak amacıyla Füzyon Antlaşması imzalanarak tek komisyon ve tek konseyli yapıya geçilmiştir (Köhler, 199; 14).

Avrupa Birliği'nin kurucu antlaşmalarından olan Roma Antlaşması ile AET kurulduğunda üye ülke sayısı altı iken 1973'te Kuzey Avrupa devletleri olan Büyük Britanya, Danimarka ve İrlanda Cumhuriyeti topluluğa dahil edilerek üye sayısı 9'a çıkarılmıştır (Stahl, 2017; 279). Daha önce de ifade edildiği gibi AET'nin öncelikli kuruluş amacı ortak bir ekonomik pazarın gerçekleştirilmesiydi. Avrupa Birliği'ne giden yoldaki diğer genişleme halkası 1981 yılında Yunanistan'ın ve 1986 yılında da Portekiz ve İspanya'nın dahil edilmesi ile gerçekleştirilmiştir (Stahl, 2017; 279). Portekiz, İspanya ve Yunanistan üye oldukları tarihlerden çok daha önce AET'ye yakınlaşmaya çalışmışlardı. Fakat demokratik olmayan askeri rejimlerle idare ediliyor olmaları bu yakınlaşmaya engel olmuştur. Ancak belli bir demokratikleşme sürecinden geçtikten sonra AET'ye üye olmalarının önü açılmıştır.

Sovyetler Birliği'nde, Devlet Başkanı Mihail Gorbatschow’un gerçekleştirmiş olduğu "Glasnost- Açıklık" ile "Perestroyka- Yeniden Yapılanma" siyasetinin Soğuk Savaş'ın sonunu hazırlaması aynı zamanda Doğu ve Batı Almanya'nın birleşmesine de vesile olmuştur. Dünya siyasetinde ve uluslararası ilişkilerde meydana gelen bu ani ve hızlı değişikliklere hazır olabilmek adına Maastricht'te bir zirve gerçekleştirilmiştir. Maastricht Zirvesi diye de tarihe geçmiş olan bu zirvede AET'yi yeni gelişmelere hazırlamak amacıyla büyük kurumsal değişikliklere gidilmiştir. Zirvede alınan kararla Maastricht Antlaşması olarak Avrupa tarihinde ayrı bir yer edinmiştir. Maastricht Antlaşması özellikle içişleri, adalet, güvenlik ve ortak dış politika gibi alanlardaki düzenlenmeleriyle birliği 
uluslararası arenadaki yeni gelişmelere hazırlama amacı taşımaktaydı (Streinz, 2012, 309).

Maastricht Antlaşması ile alınan önemli kararlardan bir tanesi de Avrupa Birliği'nin (AB) kurulması kararıdır. Bu Antlaşma AET'nin dünyada meydana gelen hızlı değişikliklere bir cevap ve reaksiyonu niteliğindedir. Alınan önemli kararlardan bir diğeri de Ekonomik ve Parasal Birliği'nin (EPB) kurulmasıdır. Ekonomik ve Parasal Birliğin sonucu daha sonra ortak bir para biriminin devreye sokulmasına kadar gitmiştir. Üye devletler ayrıca dış ve güvenlik politikaları ile içişleri ve adalet alanlarında daha derin koordinasyona gidilmesine de karar vermişlerdir. Birliğin adının Avrupa Ekonomik Topluğu'ndan (AET) Avrupa Birliği olarak (AB) değiştirilmesi Avrupa tarihinde önemli dönüm notlarındandır. AET ile üye devletler arasında salt ekonomik alanda olan iş birliği bundan böyle AB ile Çevre Koruma ve Tüketici Hakları gibi siyasi konuları da içermeye başlamıştır.

AB'yi bu yıllarda meşgul eden konulardan bir tanesi de Soğuk Savaş’tan sonraki süreçte kıta Avrupa'sındaki siyasi bölünmenin ortadan kalkması ile oluşan belirsizliğin nasıl çözüleceğiydi. Daha önceki yıllardaki genişleme etapları ile Birliğe üye ülkelerin sayısı 6'dan 15'e yükselmiş, Doğu Avrupa ülkeleri Sovyetler Birliği'nin dağılması ve akabinde de Varşova Paktı'nın kendini lağvetmesiyle özgürlüklerine kavuşmuştur. Bu yıllara kadar Batı Avrupa devletlerinden oluşan $\mathrm{AB}$ üye devletlerinin ortak görüşü, artık özgür olan Doğu Avrupa devletlerinin sistem değişikliğini gerçekleştirdikten sonra $\mathrm{AB}$ 'ye üye olmalarının önünün açılmasıydı. AB aday ülkelerin belli standartlara kavuşmaları için belirli kriterleri yerine getirmeleri gerekiyordu. Bu kriterleri belirlemek amaciyla 1993 yılında Danimarka'nın başkenti Kopenhag'da bir Zirve gerçekleştirilmiştir. Zirvede belirlenen kriterler daha sonra Kopenhag Kriterleri olarak tarihe geçmiştir. AB'ye üye olmak için yerine getirilmesi gereken kriterler siyasi, ekonomik ve üyelik müfredatının benimsenmesi esasları üzerine kurulmuştur (Smolka, 2019; 41).

Üyelik başvurusunu 1987 yılında dönemin Avrupa Ekonomik Topluluğu'na (AET) sunmuş olan Türkiye'nin de Kopenhag'da belirlenen kriterleri yerine getirmesi gerekiyordu. Türkiye ve diğer aday ülkelerden serbest piyasa ekonomisi, hukukun üstünlügünü sağlayan bir kurumsal yapı, insan haklarına saygılı ve sivil özgürlükleri sağlayan bir devlet anlayışına sahip olmaları bekleniyordu (Smolka, 2019; 41). Tam üyelik başvurularını Türkiye'den y1llar sonra gerçekleştirmiş olan Doğu Avrupa ülkeleri 2004 ve 2007 yıllarında iki etap halinde AB'ye dahil oldular. Kopenhag Kriterleri'ni yerine getirerek AB'ye en son üye olan devlet Hırvatistan'dır. AB'nin her üye sayısını artırma kararı, aynı zamanda Birliğin siyasi hareket kabiliyetini de kısıtlamıştır. Bu kabiliyetini artırmak amacıyla $\mathrm{AB}$, sürekli yeni düzenlemeler getirmek zorunda kalmıştır (Reiter, 2011; 79).

Kurumlar çerçevesinde yapılan reformlarda istedikleri başarıyı elde edemeyen AB yetkilileri Amsterdam ve Nice Antlaşmaları ile Birliğin karar mekanizmalarının 
bloke edilme ihtimalini ortadan kaldırmak amacıyla gelişmiş iş birliği prosedürünü devreye sokmuştur (Thym, 2004; 47). Birlik bünyesindeki entegrasyonu geliştirmek amaciyla yapılan bu düzenlemelerle üye ülkeler kurumsal anlamda da adım atabilecek duruma gelmiştir. $\mathrm{Bu}$ düzenlemeler gerçekleştirilirken AB'ye üye ülkelerin hepsi doğal olarak aynı fikir etrafında toplanmadılar. Schengen ve Parasal Birlik anlaşmalarını incelediğimizde üye devletlerin bazılarının bu anlaşmalara dahil olmadıklarını görmekteyiz. Schengen ve Parasal Birlik anlaşmalarına bütün üyelerin dahil olmamaları AB içerisinde siyasi ve kurumsal anlamdaki derinleşmenin bütün üyeler tarafından aynı şekilde benimsenmediğini göstermektedir. Böylece AB üyeleri arasında iki farklı gelişme ve iki farklı görüş olduğu anlaşılmaktadır. "İki farklı hız" olarak da ifade edilen bu gelişme AB'nin bölünmesine yol açma potansiyelinden dolayı bazı çevreler tarafından yoğun eleştiriye maruz kalmıştır (Heckel, 199; 52).

Birlik dahilinde sorun teşkil eden diğer bir konu ise $\mathrm{AB}$ Komisyonu'nun verimliliğidir. AB Komisyonundaki komiserlerin sayısı 1952 yılında sadece 9 iken 2007 yılında 27 üyeye çıkmıştır. Üye ülkelerin 2004 yılına kadar komisyona gönderdikleri üye sayısı, ülke başına iki üyeden oluşmaktaydı. Doğu Avrupa ülkelerinin $\mathrm{AB}$ 'ye dahil olmasından sonra, şişkinlik olmaması adına ülke başına düşen komiser sayısı ikiden bire indirilmiştir. Komisyonu'nun kurulduğu ilk y1llarda toplam komiser sayısı 9 üyeden oluşurken, zamanla bu sayı 28'e kadar yükselmiştir. En son halini ise Büyük Britanya'nın AB'den ayrılmasıyla geriye kalan 27 üye ülkeden gönderilen birer komiserden oluşmasıyla almıştır (Paschke ve Iliopoulus, 2006; 160-161).

AB'de oluşan sorunları görüşmek amacıyla 2001 yılında AB'ye üye devletlerin devlet ve hükümet başkanları bir araya gelerek bir zirve gerçekleştirdiler. AB'nin bu Zirvesi'nde karar alma süreçlerini daha verimli ve demokratik hale getirebilmek amacıyla bir temel sözleşme hazırladılar. Hazırlanan bu temel sözleşme 2004 yılında Roma'da Avrupa Anayasası olarak üye ülkelerin Zirve'ye katılmış olan devlet ve hükümet başkanlarınca imzalanarak onaylandı. Yeni bir süreç olan Avrupa Anayasası'nda çoğunluk kuralına göre alınan kararların artırılması, AB Komisyonu'nun küçültülmesi ve AB'nin ortak dış politikasının daha koordineli bir hal alması gibi konular düzenlendi.

AB Anayasası'nın yürürlüğe girebilmesi için üye ülkeler tarafından onaylanması gerekiyordu. Bazı ülkeler AB Anayasası'nın onaylama sürecini parlamentolarında; bazı ülkeler ise zorunlu olmamasına rağmen vatandaşlarının karar vermeleri adına referandumlar gerçekleştirdiler. Fransa ve Hollanda halk oylaması yolunu seçen ülkelerdi ve 2005 yılında halk oylamalarını gerçekleştirdiler. İki ülkede de yapılan referandumlarda Fransa ve Hollanda seçmenlerinin çoğunluğu AB Anayasası'nı reddedince AB Anayasa'nın yürürlüğe girmesi engellenmiş oldu (Schünemann, 2017; 96). Fransa ve Hollanda'daki halk oylamalarının sonucu AB Anayasası aleyhine olmuş olsa bile AB içerisindeki entegrasyon devam etmeliydi. Bu amaçla 2007 y1lında Portekiz'in başkenti 
Lizbon'da yeni bir AB Zirvesi oluşturuldu. Daha önce hazırlanmış olan Avrupa Anayasası'nın adı ve muhteviyatının bazı bölümleri değiştirilerek Lizbon Antlaşması diye adlandırıldı. Avrupa Anayasası taslağında AB Parlamentosu'nun işleyişi yeterince demokratik olmadığı eleştiri konusu olmuştu. Yapılan bu eleştiriler dikkate alınarak doğrudan demokrasiye verilen önem Lizbon Antlaşması'nda artırıldığı görülmektedir. Avrupa Anayasası olarak başlayan bu süreç Lizbon Antlaşması olarak yeniden kamuoyu ile paylaşılarak İrlanda'da yapılacak olan halk oylaması ile sonlandırılmak istenmiştir (Gentinetta, 2014; 97). İrlanda'da 2008 yılında yapılan halk oylamasında Lizbon Antlaşması daha önce Fransa ve Hollanda da reddedildiği gibi İrlandalı seçmenler tarafından da reddedilmiştir. Bu süreci olumlu bir şekilde sonlandırmak isteyen AB bir y1l sonra tekrar bir halk oylaması yapılması kararı almıştır. Bir yıl boyunca AB'nin olumlu yönleri seçmenlere detaylı bir şekilde anlatılınca, düzenlenen ikinci halk oylamasında İrlandalıların çoğunluğu Lizbon Antlaşmasına gerekli desteği vermişlerdir (Kamps, 2014; 443).

Lizbon Antlaşmasının temel amacı başarısız bir onaylama sürecinden geçmiş olan AB Anayasası'nı Lizbon Antlaşması olarak adlandırarak yürürlüğe girmesini sağlamaktı. Nitekim Avrupa Anayasası'ndaki düzenlemelerin bir kısmı değiştirilmiş ve Lizbon Antlaşması diye AB kamuoyuna sunulmuştur. Avrupa Anayasası ile AB'nin demokratik eksiklikler giderilmeye çalışılmış, Lizbon Antlaşması'nda da AB Anayasa taslağındaki eksiklikler giderilerek AB'nin daha demokratik olması beklentisiyle hayata geçirilmiştir. $\mathrm{Bu}$ anlamda, AB'nin kurumlar arası koordinasyon mekanizmaları genişletilmiş ve $A B$ kurumlarını daha etkin kılabilmek adına üye devletlerin veto haklarına kısıtlamalar getirilmiştir. Ayrıca AB'nin demokratik meşruiyetini artırmak amacıyla da AB kurumlarından olan Parlamentonun sorumluluğu artırılmıştır. AB Parlamentosu'nun sorumluluğunu artırılmasına ilaveten diğer $\mathrm{AB}$ kurumlarının yetki ve sorumlulukları AB'nin artacak üye sayısına göre hazırlanmaya çalışılmıştır (Schild, 2010; 31).

Lizbon Antlaşması'nın diğer bir adı da AB Antlaşması olarak tarihe geçmiştir. Bu Antlaşmanın 49. maddesine göre $A B$ 'ye üye olmak isteyen bütün devletler AB'nin temel değerlerini kabul etmek zorundadırlar. Antlaşmada geçen "Bütün Avrupa devletleri" ifadesinin geniş anlamda idrak edilmesi gerekmektedir. aslında coğrafi olarak Asya'da bulunan ama Avrupa Konseyine üye olan devletleri de bu kategoriye dahil etmektedir (Slavu, 2008; 59). Üye olabilme şartları, yukarıda da ifade edildiği gibi Kopenhag Kriterleri'nin yerine getirilmesidir. Aday ülkelerin Kopenhag Kriterlerini yerine getirip AB'ye hazır hale gelebilmeleri için AB her bir aday ülkeye Birliğin çeşitli fonlarından hem danışsal hem de maddi yardımlardan faydalanma imkanını sağlamıştır. AB Katılım Ortaklıkları çerçevesinde aday ülkelerin $\mathrm{AB}$ standartlarını yakalamaları için de ayrıca çalışmalar gerçekleştirilmektedir. Aday ülkenin katılım sürecinin son aşamasını Katılım Antlaşması oluşturmaktadır. Bu antlaşmanın bütün üyeler, aday ülkeler ve AB Parlamentosu tarafindan onaylanması gerekmektedir. 
$\mathrm{AB}$ ile ilgili terminolojide kullanılan "potansiyel aday ülke" ile "aday ülke" terimlerinin birbirine karıştırılmaması gerekmektedir. Günümüzde AB'ye aday ülke statüsünü kazanmış beş ülke bulunmaktadır. Aday ülkelerden birisi olan Türkiye 2005 yılından bu yana üyelik görüşmelerini sürdürmektedir. $\mathrm{AB}$ daha önce başka hiçbir aday ülke ile bu kadar uzun adaylık görüşmeleri gerçekleştirmemiştir. AB’ye adaylık statüsü kazanmış diğer ülkeler Makedonya, Karadağ, Surbistan ve Arnavutluk'tur. Makedonya 2005, Karadağ 2010, Sirbistan 2012, Arnavutluk 2014 yıllarında üyelik statüsü kazanmıştır. Üyelik statüsüne sahip olmak aynı zamanda adaylık görüşmelerinin başladığı anlamını da taşımaktadır. AB 2019 yılı Aralık ayı itibariyle üyelik görüşmeleri Türkiye, Sırbistan ve Karadağ ile sürdürmektedir. Potansiyel aday ülke statüsünde olan ülkelerin ise Bosna Hersek ve Kosova olduğu, AB'nin resmî açıklamalarından anlaşılmaktadır (AB, 2019). Kosova'nın durumu diğer ülkelere göre biraz farklılık göstermektedir. AB'ye üye 27 ülkenin sadece 23'ü Kosova'nın bağımsızlı̆̆ını tanırken, İspanya, Yunanistan, Güney Kıbrıs Yönetimi, Slovakya ve Romanya Kosova'nın bağımsızlığını halen tanımamaktadırlar (Paneuropa, 2019).

Özellikle Balkan coğrafyasındaki potansiyel etnik çatışmaları ortadan kaldırmak adına bu ülkelerin $A B$ 'ye üye olması son derece elzem gözükmektedir. AB'nin olası savaşları engelleme misyonu Balkan coğrafyasındaki etnik sıkıntıların ortadan kaldırılmasına yardımcı olacağından bu ülkelerin üyeliğe kabul edilmesi Avrupa Kıtası'nın geleceği açısından son derece önemlidir. Fakat 2019 yılı itibariyle aday ülkelerin üyeliğe kabul edilmesi Brexit öncesine göre biraz daha zor gözükmektedir. AB, Büyük Britanya'daki halk oylamasından (Brexit) sonra özellikle iki önemli sorunla mücadele etmek zorunda kalmıştır. Bunlardan biri, Brexit' in $\mathrm{AB}$ üyesi ülkelerde mevcut aşırı sağ sorununu daha da arttırması, diğeri ise AB'nin kendi bünyesinde kurumsal düzenlemelere ihtiyaç duymasıdır.

\section{AB'nin Geleceğini Belirleyecek Olan Dahili Sorunlar}

\subsection{Brexit - Büyük Britanya'nın AB'den ayrılması}

Son yüzyıllarda giderek büyüyen ve hatta bir dönem üzerinde güneş batmayan imparatorluk olarak nitelendirilen Birleşik Krallık son iki dünya savaşından da galibiyetle ayrılmayı başarmıştır. Büyük Britanya, İkinci Dünya Savaşı'ndan sonra dünya siyasetini düzenleyebilen büyük güç olma kapasitesinden giderek ödün vermek zorunda kalmıştır. Dünya siyasetinde etkisi azalan Büyük Britanya'ya paralel olarak etkisi yükselen Amerika Birleşik Devletleri olmuştur. İkinci Dünya Savaşı'ndan sonra, daha önceki yıllarda da dile getirilen Avrupa'da Birlik oluşturulma fikri iyice alevlenirken Büyük Britanya kendisini bu gelişmelerin dışında tutmaya özen göstermiştir. Öyle ki Büyük Britanya tarihinin en önemli siyasetçilerinden biri olan Sir Winston Churchill 1946 yılında Zürih Üniversitesi'nde gerçekleştirmiş olduğu meşhur konuşmasında Avrupa'da bir birliğin kurulması gerektiğini ifade ederken, ülkesi Büyük Britanya'yı bu birliğin içerisinde görmemekteydi. Churchill'e göre de Avrupa'da bir Birlik kurulmalı fakat Birlik Kıta Avrupası ülkelerinden oluşmalıydı (Ukshini, 2020; 31). Büyük 
Britanya 1950'li yılların sonlarından itibaren bu fikrini değiştirmiş ve AET'ye üyelik başvurusunda bulunmuştur. Fransa'nın muhafazakâr devlet başkanı De Gaulle uzun yıllar Büyük Britanya'nın üyeliğine karşı çıkmış ve üyeliğini veto etmeyi başarabilmiştir. Fransa merkezli ortaya çıkan 1968 olayları De Gaulle hükümetinin sonunu getirmiş ve De Gaulle'den sonra iktidara gelen Sosyalistler Büyük Britanya'nın üye olmasına karşı gelmemiş ve böylece Büyük Britanya'nın üyeliğinin yolu açılmıştır. Büyük Britanya'nın AB'ye üye olmasından sonra dahi Brüksel ile olan görüş farklılıkları devam etmiștir. İngiliz siyasetin önemli isimleri olan Margaret Thatcher, Tony Blair ve David Cameron gibi Başbakanlar Brüksel'le aynı görüşe sahip olma adına özel bir çaba sarf etmemişlerdir. Büyük Britanya hükümetleri, ülkede meydana gelen her türlü ekonomik sıkıntı ve krizlerde suçlu olarak AB'nin başkenti Brüksel'deki bürokratları sorumlu tutma yoluna başvurmuşlardır. Büyük Britanya ve AB'nin çıkarları Büyük Britanya'nın üye olmasından sonraki yıllarda da birbiri ile pek fazla örtüşmemiştir. Londra'daki hükümet ile AB'nin yetkilileri arasındaki çekișmelere verilebilecek en güzel örneklerden birisi 1979 yılında gerçekleștirilen görüşmelerde Margaret Thatcher'in kullanmış olduğu "I want my money back" ifadesidir. Thatcher' in katı pazarlık kabiliyetinin sonucunda $\mathrm{AB}$, Büyük Britanyalılara "Britanya indirimi" diye özel bir indirim uygulamak zorunda kalmıştır (Weidenfeld, 2015; 171).

Büyük Britanya, AB'ye üye olmasıyla beraber Birliğin kendisi gibi liberal ekonomi politikaları uygulaması için sürekli telkinlerde bulunmuştur. AB'nin genişleme süreçlerinde yeni üyelerin Birliğe dahil olmasını desteklemekle beraber, Birliğin siyasi entegrasyonunun derinleşmesine karşı çıkmaktan geri kalmamıştır. Büyük Britanya'yı AB'nin lokomotif ülkeleri olan Fransa ve Almanya'dan ayıran en önemli konulardan birisi AB'nin siyasi bir birliğe doğru evrilmesine karşı çıkıyor olmasıydı. İngiltere liderliğindeki Büyük Britanya'nın Schengen Antlaşması, avro ile Ekonomik ve Parasal Birlik adımlarına dahil olmaması, bu tutumun bir göstergesi olarak karşımızda durmaktadır.

Londra ile Brüksel arasındaki göze çarpan diğer farklı görüş ise Suriyelilerin savaştan kaçarak Avrupa'da büyük bir göçmen krizine neden olduğu dönemde, Britanya hükümetinin göçmenlerin ülkelerine gelmelerine karşı çıkmasıdır. Bu süreç içerisinde $\mathrm{AB}$ tarafından alınan önlemlerden bir tanesi de $\mathrm{AB}$ 'ye üye ülke vatandaşlarının AB'deki serbest dolaşım haklarının kısıtlanmasıdır ki, bu kararda Büyük Britanya'daki Brexit taraftarlarınca kabul görmüştür. Bu tür önlemler ve gelişmeler $\mathrm{AB}$ düşmanı olan Brexit taraftarları arasında artan bir yabancı düșmanlığının da olduğunu göstermektedir. $A B$ düşmanlığı ile yabancı düşmanlığı üzerine kurulu kampanyaların gerçekleştirilmesi, Büyük Britanya'daki popülist siyasetin ulaşmış olduğu boyutların göstergesidir. Büyük Britanya'da yabancılara karşı oluşan bu olumsuz havayı ilk olarak hissedenler AB'nin genişleme süreçlerinin birinde Birliğe dahil olan Polonya'lı göçmen işçiler olmuştur (Die Zeit, 2019). 
Brexit oylamasının sonucunu etkileyen sebeplerden bir diğeri de hem Büyük Britanya'da hem de AB'de artan sosyal adaletsizliktir. Gelir grupları arasındaki makasın giderek artması Brexit oylamasının sonucunu belirlemekle birlikte AB içinde de önemli bir sorun haline gelmiştir. Diğer AB ülkelerinde de olduğu gibi Büyük Britanya'lılar da içinde bulundukları krizlerin yegâne sorumlusu olarak AB'yi görmüşlerdir. Göçmen ve yabancılar konusunda da AB'nin göçmen ve yabancılara özgürlükler tanıdığı algısı Büyük Britanyalılara göre ülkedeki yabancıların sayısının artmasına sebep olmuştur.

Büyük Britanya'yı oluşturan Galler, İngiltere, İskoçya ve Kuzey İrlanda seçmenlerinin Brexit halk oylamasındaki farklı tavırları dikkatlerden kaçmamaktadır. Büyük Britanya'yı oluşturan ülkeler ayrı ayrı mercek altına alındığında Brexit oylamasının sonuçlarının birbirinden çok farklı olduğu gözükmektedir; İngiltere ve Galler seçmenin çoğunluğu AB'den ayrılmak yönünde oy kullanırken İskoçya, Kuzey İrlanda ve Cebeli Tarık seçmenin çoğunluğu Birlik’te kalmak yönünde oy kullanmıştır (Albert, 2018; 119). Brexit halk oylamasının sonucu AB için son derece önemli olmakla beraber, Büyük Britanya'nın geleceğini belirleme potansiyeline de sahiptir. Öyle ki Brexit Büyük Britanya'nın sonunun başlangıcı olma ihtimalini bile taşımaktadır.

Halk oylamasının sonucu göstermiştir ki, Büyük Britanya'yı oluşturan her bir devletin seçmeni AB'yi farklı farklı değerlendirmektedir. İskoçların halk oylamasında büyük çoğunluğun AB'de kalma yönünde oy kullanması Büyük Britanya'nın geleceği için büyük sorunları beraberinde getirmektedir. İskoç milliyetçilerinin talepleri doğrultusunda 2014 yılında gerçekleştirilen Birleşik Krallık' tan ayrılma halk oylamasında seçmenlerin \%62 Büyük Britanya'da kalma yönünde oy kullanmıştır (Janice, 2017; 103). Büyük Britanya'dan ayrılma halk oylamasının sonucundan memnun olmayan İskoç milliyetçileri için Brexit halk oylaması yeni bir firsat doğurmuştur. İskoçya'daki Brexit oylaması sonucunda halkın 2/3'sinin AB'de kalma yönünde oy kullanmış olması İskoç milliyetçilerinin Brexit sonucunu kendi çıkarları için kullanıp tekrar Büyük Britanya'dan ayrılma yönünde halk oylaması talebinde bulunma ihtimalini güçlendirmektedir. Gerçekleştirilecek olan yeni bir halk oylamasında Büyük Britanya'dan ayrılacağız ama aynı zamanda daha güçlü bir Birlik olan AB'de kalacağız vaadi İskoç milliyetçilerinin istediklerini elde etme ihtimalini artırmaktadır. Benzer bir senaryo AB'de kalma yönünde oy kullanılan Kuzey İrlanda için de söz konusu olabilir. $\mathrm{Bu}$ ihtimallerden herhangi birinin gerçekleşmesi durumunda dahi Brexit' in Büyük Britanya için ne kadar tehlikeli sonuçlar doğurabilme potansiyeline sahip olduğunu göstermektedir.

Günümüz Avrupa'sının en önemli devletlerinden birisi olan Büyük Britanya dünya tarihi açısından da son derece büyük bir öneme sahiptir. Siyasi, askeri ve ekonomik gücü ile 20. yüzyıla kadar dünya siyasetine yön vermiş olan bir devletin AB'den ayrılmış olması Birliği hem siyasi hem de ekonomik olarak olumsuz etkilemiştir. Nihai hedefi tanımlanmamış bir siyasi entegrasyon yolunda ilerleyen 
AB, Büyük Britanya'nın ayrılması ile büyük bir şok yaşamıştır. Büyük Britanya'nın Brexit halk oylamasının sonucunda AB'den ayrılmış olması geriye kalan diğer üye ülkelere örnek teşkil edebilecek bir potansiyele sahiptir. AB'nin başlangıcı olarak kabul edilen AKÇT'den bu yana Birliğe üye olmuş hiçbir ülke Birlikten ayrılmamıştır. Büyük Britanya'nın AB'den ayrılması bu anlamda ilktir ve Birlikten hoşnut olmayan kamuoylarının, hükümetlere ayrılma yönünde baskı oluşturması potansiyeline sahiptir.

\subsection{Artan Göçmen Sorunu}

Küreselleşme sürecinin bütün boyutları ile hız kazanması Avrupa kıtasına olan göçlerin artmasına sebep olmuştur. Küreselleşme birçok olumlu sonucun yanında elbette olumsuz sonuçları da beraberinde getirmiştir. Olumsuz sonuçlardan bir tanesi ve bizim konumuz açısından önemli olanı dünyada zengin ve yoksul ülkeler arasındaki makasın giderek açılmasıdır. Refah seviyesi artan bir AB'ye karşın refah seviyesinde olumlu anlamda hiçbir değişiklik olmayan ve böylece vatandaşlarına bir gelecek vizyonu sunamayan, işsizlikle mücadelede başarısız olan ülkelerin vatandaşları için $\mathrm{AB}$ bir cazibe merkezi olmaya devam etmiştir. Böylece AB'ye nazaran gelir seviyesi son derece düşük olan bu ülkelerden AB'ye göç etmek isteyen insanların sayısında son yıllarda sürekli artış meydana gelmektedir.

Dünyanın sayılı kriz merkezlerinden biri olan Orta Doğu son yıllardaki siyasi krizler ve bu krizleri takip eden savaşlardan dolayı göç vermektedir. Orta Doğu'daki krizlerden önce Afrika ve Asya devletlerinden önemli sayıda göçe maruz kalan AB devletleri, Orta Doğu'daki gelişmelerden sonra ayrıca bu ülkelerden de göç almaya başlamıştır. Özellikle Suriye'deki iç savaşın sebep olduğu göç dalgaları AB ülkelerini zor durumda bırakmıştır. Suriye'deki iç savaştan kaçarak Avrupa'ya doğru gitmek isteyen göçmenlerin kullanmış oldukları güzergahların başında Balkan güzergahı gelmektedir. Ülkelerindeki iç savaştan kaçan Suriyelilerin büyük bir kısmının tercih ettikleri ülkelerin başında Türkiye gelmektedir. Türkiye'ye sığınan Suriyelilerin, Yabancılar ve Uluslararası Koruma Kanunu'nun 91. maddesine dayanılarak çıkartılan Geçici Koruma Yönetmeliği'ne göre Türkiye'de kalmalarına izin verilmektedir (Bostan, 2018; 48). AB ile Türkiye arasındaki görüşmelerden istediği sonucu elde edemeyen Türkiye hükümeti 2015 yılının yaz aylarında Türkiye'de bulunan ve AB ülkelerine gitmek isteyen Suriyeli ve diğer ülkelerden oluşan göçmenlerin Avrupa'ya doğru gidebilmeleri için Yunanistan ve Bulgaristan'a olan sınır kapılarını açması $\mathrm{AB}$ ülkelerinde büyük bir krizin yaşanmasına sebep olmuştur. Türkiye'den AB üyesi olan Balkan ülkelerine geçerek özellikle Almanya'ya doğru giden göçmenlerin sayısının birkaç hafta içerisinde bir milyona ulaşması $\mathrm{AB}$ ülkelerini büyük bir çaresizlikle karşı karşıya bırakmış ve aynı zamanda AB'nin Göçmen ve Mülteciler konusunda Birlik gibi hareket edemediğinin ortaya çıkmasına neden olmuştur (GPPİ, 2015). 
AB ülkelerine gitmek isteyen göçmenlerin sayısındaki bu büyük artış sadece Büyük Britanya'daki halk oylamasının sonucunu değil aynı zamanda çeşitli $\mathrm{AB}$ ülkelerindeki mevcut iktidarların göçmen politikalarında değişikliklere gitmelerine de sebep olmuştur. Bir milyon civarında Suriyeli göçmen böylece 2015 yılında $A B$ ülkelerindeki aşırı sağ partilerin oylarının artmasına katkıda bulunmuştur (Die Zeit, 2019). Seçmenlerin birçoğuna göre mevcut iktidarlar göçmenlere karşı yeterince sert politika izlemeyip ülkelerine girmelerine müsaade ettikleri için oy tercihlerini aşırı sağ ırkçı partilerden yana kullanmışlardır. $\mathrm{Bu}$ süreçte $\mathrm{AB}$ ülkelerindeki 1rkçı aşırı sağ partilerin ortak görüşlerinden biri, göçmenlerin ülkelerine sokulmaması gerektiği düşüncesi olmuştur.

Krizin büyüklügünü anlatabilmek adına verilebilecek örneklerin başında Almanların Suriyeli göçmenlerin oluşturduğu kriz ortamını "Jahrhundertproblem- yüzyılın sorunu" olarak nitelendirmeleridir (Schid Noerr, 2017; 8). Avrupa'da Suriyeli göçmen krizinin zirveye ulaştığ 2015 yılının Eylül ayında Almanya Şansölyesi Angela Merkel, Dublin Sözleşmesi'ne aykırı hareket ederek Avusturya ve Macaristan sınırında bekleyen göçmenlerin kayıtları alınmadan Almanya'ya devam etmelerine müsaade etmiştir (Bild, 2020). Merkel'in Dublin Sözleşmesine aykırı hareketi sadece göçmenler tarafından değil aynı zamanda krizin insani boyutunu değerlendiren Alman kamuoyu tarafindan da olumlu karşılanmıştır. Oyları giderek artıran aşırı sağ partilere rağmen Şansölye Angela Merkel'in Suriyeli göçmenlere karşı takınmış olduğu olumlu tutumun amacı sadece savaştan dolayı ülkelerinden göç etmek zorunda kalmış olan insanlara karşı hümanist bir yaklaşım sergilemek değildir; Şansölye Merkel bu hareketi ile aynı zamanda, ortak manasını yitirmiş bir siyasi Birliği kurtarmayı arzulamıştır

Suriyeli göçmen krizinin zirve yaptığı bu dönemde AB ülkelerinde göçmenlere karşı farklı farklı tutumlar olduğu da göze çarpmaktaydı. Bir yanda, Türkiye üzerinden yürüyerek Viyana ve Münih gibi şehirlere ulaşmış olan Suriyelileri alkışlar arasında yemek ve içecek ikram ederek karşılayan Alman ve Avusturyalılara şahit olunurken, diğer yandan da dikenli tellerle durdurulmaya çalışılan göçmenler görülmekteydi. Karşılaşılan bu manzaralar aslında AB'nin kendi içerisinde ne kadar farklı tutumlar barındırdığının bir delilidir. AB kamuoyunun sergilemiş olduğu bu tezat görüntülerin yanında, Doğu Avrupa devletleri Macaristan, Çekya ve Polonya gibi ülkelerden yükselen, "kabul edeceksek Hristiyan mülteci kabul edelim” (NZZ, 2019) sesleri sadece Müslüman ülkelerde değil aynı zamanda da AB'nin Almanya gibi liberal ülkelerinde şaşkınlıkla karşılanmıştır. AB'ye üye Doğu Avrupa ülkelerinin arasında siyasi anlamda ne kadar farklı görüşler olsa bile özellikle göçmenler konusunda aynı fikir etrafında birleştikleri görülmektedir. Polonya, Macaristan, Çekya ve Slovakya gibi devletler mülteci krizi konusunda aralarındaki dayanışmayı artırmış ve hatta iş birliğine dahi gitmişlerdir. Adı geçen Doğu Avrupa devletleri kendi güvenliklerini sağlamak amacıyla birbirlerine yaklaşırken, aslında sadece kendilerini göçmenlere karşı nasıl koruyabiliriz kaygısı ile hareket etmekteydiler. 
Suriyeli göçmenler özellikle Almanya gibi Batı Avrupa devletlerini tercih etmiş olmalarına rağmen, tercih etmedikleri Doğu Avrupa ülkeleri birbirlerine yaklaştırarak göçmenlere karşı ortak tavır takınmalarına sebep olmuştur.

AB'de son yıllarda yaşanan en önemli krizlerden biri olan Suriyeli Göçmenler Krizi üye ülkelerde farklı tepkilere sebep olmakla beraber, AB ülkelerinde Müslümanlara karşı olumsuz yaklaşımların artmasına sebep olmuştur. Suriyeli göçmenler AB'de Müslüman düşmanlığının artmasına ve böylece de 1rkçı aşırı sağ partilerin yapılan mahalli ve merkezi seçimlerde oy oranlarını artırmalarına yardımcı olmuştur. Özellikle ifade edilmesi gereken ülkeler arasında Birliğin lokomotifleri olarak kabul edilen ve Avrupa'daki birleşmenin öncüleri olan Almanya ve Fransa gelmektedir.

\subsection{Küresel Ekonomik Kriz ve Etkileri}

Küreselleşme sürecinde serbest ticaret ile birçok kişi zengin olurken buna karşın birçok kişi de fakirleşerek alışık olduğu sosyal güvencelerini kaybetmiştir. Son yıllarda geleneksel yönetim şeklinden yeni bir yönetim şekli olan yönetişime geçilmesi kamuoyunun ayrıca tedirgin olmasına sebep olmuştur. Siyasi kararları artık yalnızca kurumlar ve idareciler değil, onlarla beraber lobilerin, partilerin, sivil toplum örgütlerinin ve sermayenin oluşturduğu büyük ve karmaşık bir yapının alması üye ülke vatandaşlarının AB'den yana olan korkularının artmasına sebep olmuştur (Christmann, 2014; 142). Siradan bir vatandaş ülkesinin uygulamakta olduğu siyaseti rahatlıkla anlarken, $\mathrm{AB}$ bürokrasisinin ve kurumlarının oluşturmuş olduğu devasa karmaşık yapının işlevlerini anlaması oldukça zor bir hale gelmiştir. Bütün bu devasa ve karmaşık bürokratik yapının siyasi süreçlerini analiz edip anlayamamak kamuoyunu, tedirgin etmektedir.

AB'de meydana gelen bu değişikliklere bir de ABD'de gayrimenkul sektöründeki gelişmelerin sebep olduğu ve kısa bir zaman içerisinde bütün dünyayı kasıp kavuran 2008 Küresel Ekonomik Krizi eklenmiştir. Krizin etkileri kendisini bütün dünyada göstermiş ve "1929 Büyük Buhranı" ile kıyaslanmaya başlanmıştır. Küresel Ekonomik Kriz ile mücadele edebilmek adına alınan önlemlerin başında öncelikli olarak devlet desteği ile bankaların kurtarılması gelmiştir. Ekonomik istikrarı tekrar yakalamak adına devlet sübvansiyonları ile bankaların kurtarılmaya çalışılmasına ilaveten, ekonomik konjonktürü hareketlendirmek amacıyla Keynesyen ekonomik politikalar uygulanmaya çalışılmıştır. Hükümetlerin hayata geçirmeye çalıştıkları bu önlemlerin sonucunda devletlerin bütçeleri ek yüklerle daha da zor durumda bırakılmıştır. Ekonomik yapısı diğer $\mathrm{AB}$ ülkelerinden daha zayıf olan güney Avrupa devletlerinde ekonomik kriz çok daha farklı sonuçlar ortaya çıkarmıştır. Bu ülkelerin birçoğu bütçe açıklarıyla karşılaşmışlar ve bu açıkları kapatmak adına vergileri artırmak zorunda kalmışlardır. Diğer AB ülkelerine nazaran adı geçen Güney Avrupa devletlerinde ekonomik kriz kendisini daha yüksek bir şekilde göstermiştir. 
Küresel Ekonomik Kriz' in akabinde yaşanan süreç Alman kamuoyunda "Euro Krise- Avro Krizi” olarak bilinmektedir. Avro Krizinin yaşandığ 1 Portekiz, İtalya, Yunanistan ve İspanya "PIGS States" (Galpin, 2017; 107) olarak anılmıştır. PIGS devletlerinin iflas etmemeleri için, başta Almanya olmak üzere Kuzey AB ülkeleri Birliği baskı altında tutarak bu ülkelere kemer sıkma politikaları uygulamaları gerektiğinin tavsiye edilmesi kararının alınmasını sağlamışlardır (Volkman, 2017; 105). Bu kararların uygulanıp uygulanmadığını kontrol etmek amaciyla AB Komisyonu, AB Merkez Bankası ve IMF'nin ortak denetimde bulunacaklarını açıklamış olmaları, adı geçen ülkelerin kamuoyları tarafindan son derece olumsuz karşılanmıştır.

Devam eden Küreselleşme süreci, Küresel Ekonomik Kriz ve Avro Krizi ile zengin ve yoksul arasındaki gelir dağılım makası hem AB ülkeleri hem de diğer ülkelerde zengin ve yoksul arasındaki gelir dağılımı farkının artmasını sağlamıştır. Özellikle AB Merkez Bankası tarafindan verilen kredilere muhtaç olan üye devletler, kredi şartlarından olan sosyal ve eğitim bütçelerindeki aşırı tasarruftan oluşan kemer sıkma politikaları maddesi ülkelerin kamuoyları tarafından son derece olumsuz karşılanmıştır. PIGS devletleri bir yandan kendi ekonomik krizleri ile uğraşırken diğer taraftan da uzak doğu ülkelerinin ihracata yönelik ekonomilerinin patlama yapmış olması, sıkıntıda olan ekonomilerine ayrıca darbe vurmuştur.

AB'ye üye Akdeniz kıyısı ülkeleri yükselen cari açıkları ile uğraşırken, diğer yandan hızlı bir şekilde yükselen genç işsizlik oranları ile mücadele etmek zorunda kalmıșlardı. Bu ülkelerin genç ișsizlik oranlarının kısa zamanda \%50’lere kadar yükselmesi ileriki yıllarda yeni toplumsal sorunların oluşmasına sahip büyük bir potansiyel olarak beklemekteydi (AB, 2019). Kriz döneminde işsiz kalan gençlerin beklentilerini iktidarlardaki merkez sağ, merkez sol veya liberal partiler karşılayamayınca, krizi yakinen yaşayanlar çareyi alternatif olabilecek partilerde aramaya başlamıştır. Bu süreçte işsiz gençlere en çok ümit vaat eden partiler siyasi yelpazenin sağındaki ırkçı aşırı sağ popülist partiler olmuştur. AB'nin lokomotif ülkeleri olarak kabul edilen Fransa ve Almanya'da da ayn PIGS devletlerinde olduğu gibi aşır sağ partiler klasikleşmiş merkez sağ ve sol partilerin oy oranlarına yaklaşarak iktidar yarışına dahil olmuşlardır. AB'nin geleceği açısından son derece önemli olan aşırı sağ partilerin oylarının artmaya devam etmesinin önüne halen geçilebilmiş değildir; ayrıca olası yeni krizlerde bu sürecin ivme kazanma ihtimali de bulunmaktadır.

\subsection{Yükselen Milliyetçilik ve Așırı Sağcı Partiler}

AB Komisyon Başkanı Jean Claude Juncker 2018 yılının Eylül ayında AB Parlamentosunda yapmış olduğu bir konuşmasında, milliyetçiliğin bir zehir olduğunu ifade etmiş ve aynı zamanda AB'nin geleceğini olumsuz etkileyebilecek çok büyük bir tehlike olduğunu da vurgulamıştır. Juncker konuşmasının devamında 1rkçı milliyetçiliğe karşı çıkmıştır. Buna mukabil vatanseverliği kabul ederek vatanını sevenlerin aynı zamanda AB'yi de sevebileceklerini dile 
getirmiştir. Bu konuşmanın devamında Avrupa devletlerine seslenerek, kendi egemenliklerini $\mathrm{AB}$ çatısı altında birleştirmeleri ile uluslararası sorunlarla mücadele edebilmenin mümkün olabileceğini ifade etmiştir (Deutsche Welle, 2019).

Yukarıdaki bölümde de kısaca ifade edildiği gibi AB ülkelerindeki 1rkçı aşırı sağ partilerin oy oranları artmaya devam etmektedir. Seçmenin ırkçı aşırı sağ partileri tercih etmesindeki sebeplerden birisi 2008 yllındaki Dünya Ekonomik Krizi ve sonuçlarıdır. Dünya Ekonomik Krizi ırkçı aşırı sağ partilerin oy oranlarını artırmalarına yeni bir ivme kazandırmıştır. 1980'li yıllarda Petrol Krizinin olumsuz etkisi devam ederken sanayide de robotlaşma sürecinin başlaması işsizlik oranlarının bu yıllarda artmasına sebep olmuştur. Avrupa ülkelerinin birçoğunda 1990'lı ve 2000'li yıllarda 1rkçı aşırı sağ partilerin yükselişleri devam etmiştir. Ülkeler bazında ele aldığımızda Avusturya ve Fransa, ırkçı aşırı sağ partilerin oy oranlarını ciddi anlamda artıran iki ülke olarak karşımıza çıkmaktadır. Irkçı aşırı sağ partilerin bu ülkelerdeki başarıları Avrupa'nın diğer ülkelerindeki ırkçı aşırı sağ partiler için örnek teşkil etmiştir. Fransa'da Jean Marie Le Pen' in partisi Front National- Ulusal Cephe ve Avusturya'da Jörg Haider'in partisi Freiheitliche Partei Österreich (FPÖ)- Avusturya Özgürlükçü Partisi, yabanc1, İslam ve Müslüman karşıtı ve 1rkçı söylemleri ile dikkat çekmiştir. Le Pen ve Haider gibi ırkçı aşırı sağcı liderlerin başarıları Avrupa'nın diğer ülkelerindeki siyasi yelpazelerde de benzer değişiklikler meydana gelmesine yardımcı olmuştur. 1990'lı yılların başlarında siyasetin alternatif ve küçük partileri durumundan olan aşırı sağc1 partiler günümüzde $\mathrm{AB}$ ülkelerinin bir kısmında koalisyon hükümetlerinin ortakları durumuna gelmiş ve ülke yönetiminde söz sahibi olmuşlardır.

Günümüzde 1rkçı aşırı sağ popülizmin bütün $\mathrm{AB}$ ülkelerini etkisi altına almış olduğuna tanıklık etmekteyiz. Artık sadece Fransa ve Avusturya değil, birliğin doğusundaki ülkeler olan Macaristan ve Polonya'nın yanında Büyük Britanya, İtalya, Yunanistan ve Almanya' da da aşırı sağ partilerin yeni jenerasyon liderleri ile oy oranlarını artırdıkları görülmektedir. Fransa'da Front National- Ulusal Cephe, İtalya'da ayrılıkçı Lega Nord-Kuzey Ligi ve Almanya'daki Alternatife für Deutschland (AfD)- Almanya için Alternatif, son zamanlarda ülkelerinin ulusal parlamentolarında kendilerini temsil etme hakkını elde etmeye başarmış aşırı sağ partilerdir.

Avrupa'nın batısında 1990'lı yıllardan itibaren giderek artan bir kamuoyu desteğini arkasına almayı başaran ırkçı aşırı sağ partilerin ortak özelliklerinden biri de özgürlükçü liberal demokrasinin temel prensipleri ile kavgalı olmalarıdır. Irkçı aşırı sağ partilere göre devlet kendileri tarafından oluşturulmalıdır. Kendilerinden farklı düşünenler ve fiziki olarak farklı olanlar ülkelerinde bulunma haklarına sahip değillerdir. Şayet ülkelerinde yaşıyorlar ise de ait olmadıkları bu toplumda fikirlerini beyan etme, siyasi katılım ve yasal korunma haklarına sahip olmamaları gerekmektedir (Schellenberg, 2019; 15). 
Irkçı Aşırı sağ partilerin seçmenleri mobilize etmekte kullandıkları en önemli argümanların başında, ülkede muktedir olan elitlerin ne ülke ne de ülke halkının menfaatleri doğrultusunda hareket etmedikleri iddiası gelmektedir. Ayrıca bir hukuk devletinin olmazsa olmazlarından olan azınlıkların korunması ve AB ile yapılmış olan antlaşmalara uyma zorunluluğunu da kabul etmemektedirler. Irkçı aşırı să̆ partiler her ne kadar AB genelinde kendi aralarında farklılıklar gösterseler dahi demokrasi ve hukuk devleti anlayışlarından dolayı genel anlamda demokrasi için bir tehlike oluşturdukları ifade edilebilir.

\subsection{Covid-19 Pandemi Süreci}

İlk olarak Çin Halk Cumhuriyeti'nin Wuhan eyaletinde ortaya çıktıktan sadece birkaç ay sonra bütün dünyaya yayılan yeni tip Covid-19 virüsü AB'nin geleceğini etkileme potansiyeline sahip yeni bir olgu haline gelmiştir. Çin Halk Cumhuriyeti'nden sonra bütün dünyaya kâbus gibi günler yaşatan Koronavirüsü yıkıcı potansiyeli ile sadece AB'nin değil aynı zamanda dünyanın geleceği ile ilgili yeni gelişmelere ve hatta yeni bir dünya düzenine sebep olacağ dillendirilmektedir. Koronavirüs'ün Çin'in Wuhan eyaletinden sonra hızlı bir şekilde yayıldığı ilk AB ülkesi İtalya'dır. İtalya hükümeti Virüsün bu kadar etkileyici olabileceğini düşünememiş olmalı ki önlem almakta oldukça geç kalmış ve virüsün yıkıcı etkilerine maruz kalmıştır. Avrupa kıtasında yeni tip Covid-19 virüsünün yıkıcı etkisine İtalya'dan sonra maruz kalan diğer bir ülke de İspanya'dır. Bu iki ülkenin yanında Fransa, Hollanda, Almanya ve artık Birliğe üye olmayan Birleşik Krallık yeni tip Koronavirüs'ün ölümcül etkisini fazlaca göstermiş olduğu diğer ülkelerdir.

Dünya çapında bir salgın halini alan yeni tip Covid-19 virüsü salgını AB'yi yeni sorunlar ile karşı karşıya getirmiştir. Üyesi olan ülkelerin tıbbi yardımına cevap verememekle beraber çareyi ülkeler arasındaki gümrük kapılarını kapatarak bulduğunu sanan $\mathrm{AB}$ aslında ne kadar aciz bir durumda olduğunu göstermiştir. Covid-19 virüsü üye ülkelerde yayılmaya devam etmekle birlikte sadece insanlar için hayati tehlike oluşturmakla kalmamış aynı zamanda AB'nin geleceğini tehdit etmeye başlamıştır. Yeni tip Covid-19 virüsüne hazırlıksız yakalan, sağlık alt yapısı ve tıbbi malzemeleri yetersiz olan İspanya ve İtalya yalnız bırakılmıştır. Vaka sayısının fazlalığı ve ölüm oranın yüksekliği ile büyük yıkım yaşayan bu iki ülke $\mathrm{AB}$ tarafından yeterince dayanışma görmediklerini ifade etmişlerdir. Hem İspanya hem de İtalya daha önceki Dünya Ekonomik Krizi'nden etkilenmiş olan ekonomilerini düzeltmeye başlamışken, yeni bir krizle mücadele etmek zorunda kalmaları daha büyük bir ekonomik krizin eşiğine gelmelerine sebep olmuştur.

İtalya Başbakanı Guiseppe Conte ve İspanya Başbakanı Pedro Sanches AB üyelerini daha fazla dayanışmaya davet ederek Corona Bonds adı altında AB Tahvillerinin yürürlüğe konmasını talep etmişlerdir (Der Tagesspiegel, 2020). Fransa ve İtalya'nın Corona Bonds tahvil talebi Almanya ve Hollanda gibi ülkelerin pek sıcak bakmaması nedeniyle reddedilmiştir (Tagesschau, 2020). İtalya hükümetinin $\mathrm{AB}$ nezdindeki taleplerinin karşılık görmemesi ülkedeki $\mathrm{AB}$ 
karşıtlığını artırmıştır. İtalya'daki AB hüsranının büyüklüğünü göstermek için iki farklı örnek verilebilir. Bu örneklerden birisi devletin en üst siyasi kurumlarından olan İtalya Temsilciler Meclisinin Başkan Yardımcısı Fabio Rampelli'nin Meclis'te asılı olan AB bayrağını alıp yerine İtalya bayrağını asmasıdır. Fabio Rampelli'nin katlayarak kaldırdığı AB bayrağına seslenerek "Belki, sonra yeniden görüşürüz, belki” diye hitap etmesi, ülkedeki hüsranın ne denli derin olduğunun dışa vurulmuş halidir (NewsFront, 2020). Diğer bir örnek ise İtalya'nın çeşitli şehirlerinde gerçekleştirilen gösterilerde, göstericiler tarafından AB bayraklarının yerlere atılmasına karşın İtalya bayraklarının dalgalandırmasıdır (ZDF, 2020).

\section{Sonuç ve Tartışma}

Ünlü Alman filozof Jürgen Habermas 2013 yllında Leuven Üniversitesi'nde dönemin AB Konseyi Başkanı Herman Van Rompuy'un da dinleyiciler arasında bulunduğu bir konferansta, AB'nin ortak bir Avrupa Sosyal Politikast uygulanması gerektiğini ifade ederek $\mathrm{AB}$ 'deki sorunun sadece ekonomik değil aynı zamanda normatif olduğunu vurgulamıştır. Habermas'a göre bunun sebebi AB'nin karar alma konusunda fazlaca stratejik, oportünist ve ürkek davranarak ulus aşırı bakış açısından yoksun, ekonomik kararlarda fazlaca sı̆g hareket etmesinde yatmaktadır. Ayrıca, AB yönetiminin yeterince dayanışma içerisinde olmadığını ve para piyasalarının emrine girmiş teknokratik bir idare olduğunu ifade etmekten çekinmemiştir (Deutsche Welle, 2020). Habermas'1n eleştirisinden yola çıktığımızda AB'de işlerin aslında kamuoyunun beklentileri doğrultusunda ilerlemediği ifade edilebilir.

AKÇT Anlaşmasının yürürlüğe girmesinden bu yana geçen yaklaşık 70 yıl içerisinde ortak bir ekonomik pazar ve siyasi anlamda da ortak bir anayasa oluşturmaya çalışılmıştır. AB kendisi için koymuş olduğu Ortak Pazar hedefine ulaşmıştır, fakat siyasi hedefin gerçekleştirilmesi bir yılan hikâyesine dönmüştür. Nihayetinde Lizbon Antlaşması ile hedeflenen AB Anayasası'nın gerçekleştirilmesi yönünde önemli bir adım atılmıştır. Bu süreçten sonra üye ülkelerin birbirlerine iyice yaklaştığı düşünülen bir dönemde Büyük Britanya'nın gerçekleştirmiş olduğu halk oylaması ile $\mathrm{AB}$ daha önce yaşamadığı bir süreçle karşı karşıya kalmıştır.

AB'nin hiç beklemediği ama yaşamak zorunda olduğu Brexit sürecinden sonra bir dağılma sürecine girip girmediği yukarıdaki konular karşısında takınacağı tavıra bağlı olacaktır. Brexit, iki tarafı keskin bir bıçak gibi hem AB'nin hem de Büyük Britanya'nın geleceği açısından büyük bir sorun oluşturmaktadır. Brexit belki de Galler, Kuzey İrlanda, İngiltere ve İskoçya tarafından oluşturulan Büyük Britanya'nın sonunun başlangıcını getirmiş olabilir. Daha önce Büyük Britanya'dan ayrılmak için halk oylamasına gitmiş fakat ayrılığı başaramamış olan İskoç milliyetçileri, Brexit ile AB'den ayrılmayı gerçekleştirmiş olan Büyük Britanya'dan ayrılarak hem bağımsızlıklarına kavuşmak hem de AB'ye üye olabilmek için yeniden referanduma gitmek istemeleri bunun bir delili olarak karşımızda durmaktadır. Brexit oylamasında İskoç seçmenin çoğunluğunun 
AB'de kalma yönünde oy kullanmış olması, İskoç milliyetçilerine bu çoğunluğun rüzgarını arkalarına alıp Büyük Britanya'ya karşı yeniden harekete geçme ortamı hazırlamıştır. İskoçya' da bu yönde tartışmaların başlamış olması Büyük Britanya için tehlike çanlarının çaldığı anlamına gelmektedir. Böylece Brexit halk oylaması sadece AB'de değil aynı zamanda Büyük Britanya'da da farklı dinamikleri harekete geçirme potansiyeli oluşturmuştur.

AB'de kendi bütünlüğünün korunması adına birtakım düzenlemeler ve yenilikler yapması gerektiği bu süreçte ortaya çıkmıştır. Birlik içerisinde şimdiye kadar eksik olduğu bilinen ve yüzyılın ünlü düşünürü Habermas'ın ifade etmesi ile farklı bir boyuta taşınmıştır. Dayanışma eksikliği giderildiği takdirde ekonomisi güçlü devletler ile daha az güçlü devletler arasında, gelir seviyesi yüksek toplumlar ile gelir seviyesi düşük olan toplumlar arasında ve maddi durumu iyi olan ve maddi durumu kötü olan bireyler arasındaki gelir seviyesindeki eşitsizliğin azalmasına yardımcı olabilecektir. AB gerekli paradigma değişimini dayanışma eksikliği ile giderdiği takdirde geleceği açısından büyük tehlike potansiyeline sahip olan sorunların çözümünde gerekli adımları atmış olacaktır. Şayet AB'nin yetkili kurumları ve üye devletlerinin devlet veya hükümet başkanları, gerekli önlemleri almayıp aynı şekilde yollarına devam edecek olursa Birliğin geleceğini farklı senaryoların beklediğini ifade etmek gerekir.

\section{Kaynakça}

Albert, C. (2018). Wie weiter in Nordirland? Die Zukunft Europas in einer Welt im Umbruch, Hilz, W. ve Nötzold, N. (Ed.), Wiesbaden, Springer Verlag.

Avrupa Birliği (2012). https://europa.eu/european-union/about-eu/history/2010today/2012/eu-nobel_de (Erişim: 22.11.2019)

Avrupa Birliği

https://ec.europa.eu/commission/presscorner/detail/de/MEMO_13_464

(Erişim: 24.12.2019)

Avrupa Birliği (2005). https://europa.eu/newsroom/highlights/specialcoverage/enlargement_de (Erişim: 12.12.2019)

Brasche, U. (2013). Europäische Integration, München, Oldenbourg Verlag.

Christmann, A. (2014). Von Government zu Governance? Zeitschrift für Vergleichende Politikwissenschaft, Comparative Governance and Politics, Special Issue 4, s. 141-167.

Deutsche Welle (2018). https://www.dw.com/de/juncker-nationalismus-größtegefahr-für-die-eu/a-45455626 (Erişim: 24.12.2019)

Deutsche Welle (2013). https://www.dw.com/de/habermas-kritisiert-europasführung/a-16775688 (Erişim: 15.01.2015) 
Diekmann, K., Koch, T. ve Reichelt, J. (2020). https://www.bundeskanzlerin.de/bkin-de/aktuelles/-leben-zu-retten-ist-daswichtigste-ziel--619098 (Erişim: 01.04.2020)

Die Zeit (2016). https://www.zeit.de/2016/43/brexit-fremdenfeindlicheuebergriffe-grossbritannien-rassismus (Erişim: 17.12.2019)

Die Zeit (2015). https://www.zeit.de/politik/ausland/2015-12/un-fluechtlingeeuropa-2015 (Erişim: 17.12.2019

Galpin, Ch. (2017). The Euro Crisis And European Indentities, Cham, Palgrave Macmillan.

Gentinetta, K. (2014). Europa als Herausforderung für die Demokratie. Scholten, H. ve Kamps, K. (Ed.), Abstimmungskampagnen, Wiesbaden, Springer Verlag.

Heckel, K. (1998). Der Föderalismus als Prinzip überstaatlicher Gemeinschaftsbildung, Berlin, Duncker \& Humblot.

Kamps, K. (2014). Wählen bis der Arzt kommt?. Heike Scholten, Klaus Kamps, Abstimmungskampagnen, Wiesbaden, Springer Verlag.

Köhler, C. (1999). Vertragliche Grundlagen der Europäischen Währungsunion, Berlin, Duncker \& Humbold.

Meier, A., Der Tagesspiegel, https://www.tagesspiegel.de/politik/streit-um-euhilfen-fuer-italien-deutschland-macht-einen-grossen-fehler/25719256.html (Erişim: 08.04.2020)

Neue Zürcher Zeitung (2019). https://www.nzz.ch/international/einwanderung-eupolen-und-ungarn-wollen-keine-fluechtlinge-ld.1519228 (Erişim: 18.12.2019)

News Front (2020). https://de.news-front.info/2020/03/31/bis-spater-einhochrangiger-italienischer-politiker-hat-die-eu-flagge-entfernt/ (Erişim: 08.07.2020)

Noerr, G. Sch. ve Meints-Stender, W. (2017). Flucht-Migration-Asyl: Globale und lokale Dimension. Zur Einleitung, Geflüchtete Menschen, Berlin, Verlag Barbara Budrich.

Paneuropa Bewegung (2018). https://www.paneuropa.at/kosovo-spanien-und-dieukraine/ (Erişim: 12.12.2019)

Paschke, M. ve Iliopoulus, C. (2006). Die Osterweiterung der Europäischen Union, Hamburg, LIT Verlag.

Reiter, R. (2011). Politiktransfer der EU, Wiesbaden, VS Verlag.

Schellenberg, B. (2019). Rechtspopulismus im europäischen VergleichKernelemente und Unterschiede, Dossier Rechtspopulismus. Bonn, Bundeszentrale für Politische Bildung. 
Schild, J. (2010). Pariser Pragmatismus, Europäische Union nach dem Vertrag von Lissabon, Geisse, O. (Ed.). Wiesbaden, Verlag für Wissenschaften.

Schmidt, J.H. (2014). Der unterschätzte Krieg, Hamburg, Disserta Verlag.

Schrafstetter, S. (1999). Die Dritte Atommacht, München, Oldenbourg Verlag.

Schünemann, W. (2017). In Vielfalt Verneint, Wiesbaden, Springer Verlag.

Slavu, St. (2008). Die Osterweiterung der Europäischen Union, Frankfurt/Main, Peter Lang Verlag.

Smolka, Th. (2019). Belastungsprobe für die Europäische Union, Wiesbaden, Springer Verlag.

Sonnickson, J. (2014). Ein Präsident für Europa: Zur Demokratisierung der Europäischen Union, Wiesbaden, Springer Verlag.

Stahl, B, (2017). Internationale Politik Verstehen, Opladen, Verlag Barbara Budrich.

Streinz, R. (2012). Europarecht, Heidelberg, C.F. Müller.

Tagesschau (2020). https://www.tagesschau.de/ausland/corona-eu-101.html (Erişim: 08.07.2020)

The Global Public Policy Institute (GPPI) (2015). https://www.gppi.net/2015/12/21/flucht-in-die-krise-ein-rueckblick-auf-dieeu-fluechtlingskrise-2015 (Erişim: 12.01.2020)

Thym, D. (2004). Ungleichzeitigkeit und Europäisches Verfassungsrecht, Berlin, Nomos Verlag.

Ukshini, S. (2020). Die Kosovo-Frage als Herausforderung der Gemeinsamen Aussen- und Sicherheitspolitik (GASP) der EU, Zürich, LIT Verlag.

Von Eynern, G. (1973). Wörterbuch zur Politischen Ökonomie, Opladen, Westdeutscher Verlag.

Volkman, E. (2017). Wirtschaftliche und soziale implikationen fiskalischer Austerität in Europa in Austerität als gesellschafltiches Projekt. Strum, R. ve Gabrile, T. (Ed.), Wiesbaden, Springer Verlag.

Weidenfeld, W. (2015). Die Europäische Union, Paderborn, UTB Verlag.

ZDF (2020). https://www.zdf.de/nachrichten/politik/coronavirus-italiendeutschland-mattiolo-100.html (Erişim: 07.08.2020) 